\title{
Efisiensi Biaya Produksi Usahatani Padi Sawah Kelompok Subak dan Non Subak di Kabupaten Kolaka
}

\author{
Muhammad Obi Kasmin ${ }^{\mathrm{a}}$, Nyoman Darsana ${ }^{\mathrm{b}}$ \\ ${ }^{a}$ Fakultas Pertanian, Universitas Sembilanbelas November Kolaka, Sulawesi Tenggara Indonesia, email: obikasmin@gmail.com \\ ${ }^{b}$ Fakultas Pertanian, Universitas Sembilanbelas November Kolaka, Sulawesi Tenggara Indonesia, email: n.darsana80.co.id@gmail.com
}

\section{Article Info}

Article history:

Received 5 Agustus 2019

Received in revised form 13 Agustus 2019 Accepted 8 September 2019

DOI

https://doi.org/10.32938/ag.v4i4.835

\section{Keywords:}

Pendapatan

Sosio-kultural

Subak

\section{Abstrak}

Pemanfaatan kearifan lokal dalam pengelolaan usahatani merupakan salah satu solusi dalam upaya untuk meningkatkan efisiensi usahatani. Salah satu bentuk kearifan lokal dalam pengelolaan usahatani padi sawah adalah subak, yang sampai saat ini masih dipertahankan oleh sebagian masyarakat yang berasal dari Pulau Bali di daerah perantauan. Masyarakat yang menerapkan sistem subak tersebut meyakini bahwa pengelolaan usahataninya lebih efisien dengan menerapkan sistem subak. Penelitian ini bertujuan untuk mengetahui pendapatan kelompok subak dan non subak dan keterkaitan antara sosio-kultural subak dengan pendapatan usahatani pad sawah. Pengumpulan data dilakukan dengan metode observasi, wawancara, dan studi literatur terhadap sampel/responden penelitian. Responden penelitian berjumlah 60, ditentukan secara purposive dan random. Analisis yang digunakan adalah analisis deskripti statistik. Hasil penelitian menunjukkan bahwa pendapatan petani kelompok subak lebih besar dibandingkan petani non subak dengan rata-rata pendapatan sebesar Rp 12.672.686,67 untuk kelompok subak dan Rp 10.198.529,41 untuk kelompok non subak. Tidak ada hubungan yang terpola antara sosio-kultural dengan jumlah pendapatan oleh masing-masing petani responden baik subak maupun non subak, akan tetapi ada kecenderungan jika nilai skor sosio-kultural tinggi maka pendapatan yang diperoleh petani juga tinggi.

\section{Pendahuluan}

Produksi padi sawah (Oryza satifa) di Sulawesi Tenggara dari tahun ke tahun terus mengalami peningkatan hal ini dapat terjadi karena bertambahnya luas areal persawahan akibat pembukaan lahan baru, peningkatan optimalisas lahan berupa pembuatan irigasi teknis hingga sampai ke desa-desa, dan kemajuan teknologi lainya misalnya metode SRI (System Of Rice Intensification), pengelolaan tanaman terpadu (PTT), sistem tanam, penyediaan alsintan dan lain lain (AAK, 2006).

Selain karena hal-hal tersebut diatas, ini juga merupakan keberhasilan para petani dan lembaga pendukung baik swasta maupun pemerintah dalam upaya meningkatkan produksi padi Di Sulawesi Tenggara. Selain itu, salah satu metode yang dapat digunakan untuk lebih meningkatkan efisiensi pengelolaan usahatani padi sawah adalah dengan mengembangkan dan memanfaatkan teknologi alternatif yang dimiliki oleh bangsa Indonesia yang telah teruji secara turun-temurun hingga saat ini, yaitu dengan memanfaatkan kearifan lokal. Indonesia memiliki potensi kearifan lokal yang luar biasa besar akan tetap potensi tersebut belum termanfaatkan dengan baik.

Salah satu teknologi yang berasal dari kearifan lokal yang dapa diandalkan dan hingga saat ini masih tetap eksis berkembang adalah teknologi sistem subak Bali (Aryawan, dkk., 2013). Saat ini subak banyak dijumpai di berbagai daerah di Indonesia salah satunya adalah di Desa Peoho Kecamatan Watubangga Kabupaten Kolaka yang bernama Subak Lingga Merta.

Subak Lingga Merta berdiri tahun 1985 adalah satu-satunya subak yang berada di Sulawesi Tenggara yang dibentuk oleh masyarakat transmigras etnis Bali yang hingga saat ini memiliki anggota sebanyak 62 anggota dengan luas lahan sawah kurang lebih 50 hektar. Segala kegiatan usahatani yang dilakukan petani subak mulai dari penentuan musim tanam hingga pascapanen semuanya diatur dalam peraturan adat subak yang disebut (awigawig subak) jika ada petani yang melanggar ketentuan ataupun tidak ikut kegiatan bersama seperti gotong royong dan lain-lain akan dikenakan denda/sanksi sesuai awig-awig subak setempat

Organisasi subak memiliki 4 (empat) elemen seperti: 1) lahan pertanian (sawah), 2) sumber air, 3) anggota subak dan 4) pura subak. Jadi dalam setiap organisasi subak keempat elemen tersebut akan selalu ada dan merupakan syarat mutlak sebuah organisasi subak. Menurut pemerhati subak seperti Pitana (1993), Windia (2002), Sutawan (2003), meyakini bahwa melestarikan subak merupakan salah satu cara untuk tetap menjaga pelestarian pertanian dan lingkungan dalam rangka pencapaian ketahanan pangan khususnya padi sawah di daerah subak tersebut berada serta dapat menjaga stabilitas lingkungan dan masyarakat dari konflik adat, agama dan etnik.

Eksisnya subak lingga merta dapat dilihat dari bagaimana mereka menjaga tradisi lokal dalam berusahatani padi sawah seperti: (1) Pendistribuasian air secara adil dan merata yang dilakukan dengan sistem gilir dari hilir ke hulu dan melakukan sistem pelampias, gotong royong membersihkan dan memperbaiki empelan, terowongan, saluran irigasi, (2) Pengendalian OPT secara mekanis, biologis maupun kimiawi, semua dilakukan secara bersama-sama dan gotong royong pada waktu yang telah ditentukan, (3) Melakukan upacara atau ritua keagamaan di sawah dan Pura subak baik di level subak maupun ditingkat individu atau sawah masing-masing, yang dilakukan dari awal musim tanam hingga pascapanen (Prabandari, dkk., 2013).

Dalam bercocok tanam, petani subak selama ini tidak pernah menghitung ataupun mengetahui secara spesifik bagaimana sebenarnya perbedaan biaya yang mereka keluarkan dan pendapatan yang di raih dari sistem bercocok tanam yang mereka lakukan dibandingkan cara bercocoktanam yang dilakukan petani non-subak lainnya. Mereka juga tidak pernah membandingkan hasil dari kedua sistem tanam yang mereka gunakan, mereka cukup bersyukur dengan apa yang telah diberikan oleh Sang Pencipta kepadanya, bersyukur ketika produksi yang diraih tinggi, serta bersabar ketika produksinya rendah (Sutawan, 2008). Penelitian ini bertujuan untuk mengetahui pendapatan dan efisiensi uusahatani padi sawah kelompok subak dan non subak serta keterkaitan antara sosio-kultural subak dengan pendapatan usahatani padi sawah.

\section{Metode}

Efisiensi usahatani padi sawah sistem tapin dan tabela yang dilakukan oleh petani subak lebih kecil dibandingkan usahatani padi sawah petani nonsubak, terdapat keterkaitan antara efisiensi usahatani dengan sosio-kultural subak. Penelitian ini dilaksanakan pada bulan Juli sampai Oktober 2018 Penentuan daerah penelitian dilakukan secara purposive (sengaja), dengan pertimbangan bahwa daerah penelitian ini merupakan satu-satunya wilayah di Kabupaten Kolaka yang menerapkan sistem subak pada pengelolaan usahatan padi sawah. Lokasi tersebut adalah Desa Peoho Kecamatan Watubangga Kabupaten Kolaka. Data-data dalam penelitian ini diperoleh melalui proses survey dan wawancara secara terstruktur dengan bantuan kuesioner. Penentuan sampel dalam penelitian ini dilakukan dengan metode sensus dengan jumlah sampel sebanyak 131 petani yang terdiri atas 62 petani subak dan 69 petani non subak.

Data yang telah dikumpulkan melalui wawancara dengan menggunakan kuesioner kemudian dianalisis dengan menggunakan rumus analisis pendapatan dengan formulasi sebagai berikut (Soekartawi, 1995):

$$
\begin{gathered}
I=T R-T C \\
T R=Q x P q \\
T C=F C-V C
\end{gathered}
$$

Keterangan:

$\mathrm{I} \quad=$ Income (pendapatan) usahatani padi sawah subak dan non subak (Rp)

$\mathrm{TR}=$ Total Revenue (penerimaan) usahatani padi sawah subak dan non subak (Rp)

$\mathrm{TC}=$ Total Cost (biaya total) usahatani padi sawah subak dan non subak (Rp)

$\mathrm{VC}=$ Variable Cost (biaya variabel) usahatani padi sawah subak dan non subak $(\mathrm{Rp})$

$\mathrm{FC}=$ Fixed Cost (biaya tetap) usahatani padi sawah subak dan non subak (Rp)

$\mathrm{Q}=$ Jumlah prouksi usahatani padi sawah subak dan non subak $(\mathrm{Kg})$

$\mathrm{Pq}=$ Harga produksi usahatani padi sawah subak dan non subak $(\mathrm{Rp} / \mathrm{Kg})$

Analisis efisiensi pada usahatani padi sawah sistem subak dan non subak dilakukan dengan menggunakan analisis Revenue Cost Ratio (R/C Ratio), sedangkan untuk mengetahui keterkaitan sosio-kultural subak dengan efisiens usahatani padi sawah sistem subak dan non subak dilakukan dengan menggunakan analisis statistik deskriptif tabel silang (Cross Tabulation) yaitu analisis yang ingin menguji apakah dua atau lebih variabel yang bersifa ketegori adalah bersifat independen (tidak berkaitan) atau dependen (berkaitan) Tinggi rendahnya skor input teknologi didasarkan atas didasarkan atas nilai tabel, dimana dimana penerapan teknoloi rendah nilainya 1 , dan penerapan teknologi sedang nilainya 2 , sedangkan penerapan teknologi tinggi nilainya 3 .

\section{Hasil dan Pembahasan}

\section{a. Pendapatan dan Efisiensi Petani Subak dan Non subak}

Pendapatan yang dihasilkan oleh petani sangat ditentukan oleh biaya produksi yang dikeluarkan. Biaya memegang peranan penting sehubungan dengan pengambilan keputusan oleh petani untuk melakukan proses produksi, karena dengan mengetahui jumlah biaya yang dikeluarkan, maka petani dapat menentukan berapa jumlah dari masing-masing jenis input yang akan digunakan dalam usahatani yang dikelolanya. Jenis-jenis input variabel yang digunakan dalam suatu usahatani padi sawah pada umumnya adalah benih, 
pupuk, pestisida lahan, dan tenaga kerja. Selain input variabel, ada juga input yang bersifat tetap dalam usahatani padi sawah seperti, pajak, iuran, sewa alat dan penyusutan peralatan.

Hasil penelitian menunjukan komponen biaya usahatani antara petani subak dan petani non-subak tidak jauh berbeda. Untuk komponen biaya variabel yang berbeda hanya pada peralatan yang digunakan dimana petani menggunakan alat yang oleh petani subak sendiri disebut kiskis, alat ini digunakan untuk proses penyiangan. Sedangkan pada komponen biaya tetap yang berbeda adalah pada petani subak terdapat biaya iuran upacara keagamaan sebesar Rp 25.000/ MT/Ayahan.

Tabel 1. Komponen Biaya, Penerimaan dan Pendapatan Petani Padi Sawah Sistem Subak dan Non-Subak di Kabupaten Kolaka, Tahun 2019

\begin{tabular}{cccc}
\hline No & Uraian & Subak (Rp) & Non-Subak (Rp) \\
\hline 1 & Biaya Tetap & $234.125,00$ & $375.952,38$ \\
2 & Biaya Variabel & $7.753 .014,01$ & $6.417 .536,41$ \\
3 & Total Biaya & $7.987 .139,01$ & $6.793 .488,79$ \\
4 & Penerimaan & $20.493 .410,00$ & $15.050 .000,00$ \\
5 & Pendapatan & $12.506 .270,99$ & $8.256 .511,21$ \\
6 & R/C Ratio & 2,56 & 2,22 \\
\hline
\end{tabular}

Tabel 1 menunjukkan bahwa rata-rata pendapatan petani padi sawah sistem subak lebih besar dibandingkan pendapatan petani non subak. Perbedaan jumlah pendapatan tersebut disebabkan karena adanya perbedaan biaya produksi yang dikeluarkan oleh masing-masing petani responden, dimana biaya tetap yang dikeluarkan oleh petani non-subak lebih besar dibandingkan petani subak. Selain itu, perbedaan tersebut juga disebabkan oleh adanya perbedaan jumlah produksi, dimana rata-rata produksi petani subak adalah sebesar $5.933,33 \mathrm{Kg}$ per hektar, sedangkan pada petani on-subak, produksinya sebesar $5.311,76 \mathrm{Kg}$ per hektar. Hasil analisis efisiensi usahatani menunjukkan bahwa usahatani padi sawah sistem subak lebih efisien dengan nilai efisiensi 2,57 dibandingkan dengan nilai efisiensi usahatani padi sawah non subak dengan nilai efisiensi sebesar 2,22.

\section{b. Keterkaitan Sosiokultural Subak dengan Pendapatan Usahatani} Padi Sawah

Untuk mengetahui keterkaitan sosiokultural subak dengan efisiensi usahatani padi sawah terlebih dahulu adalah dengan menghitung nilai skor dari masing-masing input sarana/teknologi yang digunakan oleh petani dan menghitung nilai pendapatan dari masing-masing sistem usahatani yang dilakukan oleh petani responden. Penggunaan teknologi yang akan dihitung nilai skornya dalam penelitian ini adalah teknologi yang digunakan dalam usahatani padi sawah yang berpengaruh langsung terhadap nilai/produksi yang diraih oleh petani responden. Teknologi tersebut mengacu pada panca usahatani, yaitu penggunaan bibit unggul, teknik pengolahan lahan, pemupukan, pengendalian organisme pengganggu tanaman dan irigasi. Tabel 2 .

Tabel 2. Tabel Silang Nilai/Skor Input Teknologi yang Digunakan Serta NilaiR/C Ratio Setiap Responden Sistem Tani Subak dan NonSubak di Kabupaten Kolaka, Tahun 2019.

\begin{tabular}{lcc}
\hline Skor Tertinggi & & R/C Ratio \\
\hline Subak & Tinggi & Rendah \\
Tinggi & 48 & 14 \\
Rendah & 0 & 0 \\
Non-Subak & Tinggi & Rendah \\
Tinggi & 39 & 28 \\
Rendah & 0 & 2 \\
\hline
\end{tabular}

Nilai R/C rata-rata subak $=2,56$

Standar Deviasi subak $=0,192$

Nilai $\mathrm{R} / \mathrm{C}$ rata-rata non subak $=2,22$

Standar Deviasi non subak $=0,155$

\section{Petani Subak}

Petani subak dengan jumlah responden sebanyak 62 responden, dimana sebanyak 48 orang responden yang skor input teknologinya tinggi memperoleh nilai efisiensi lebih besar dari nilai efisiensi rata-rata petani subak yang hanya sebesar 2,56. Artinya, terdapat 48 orang responden yang nilai efisiensi usahataninya lebih besar dari 2,56. Namun demikian, terdapat 14 orang petani responden yang skor input teknologinya tinggi tetapi memperoleh nilai efisiensi dibawah rata-rata nilai efisiensi petani subak, atau dengan kata lain, terdapat 14 orang petani responden yang nilai efisiensinya dibawah 2,56. Hasil penelitian ini juga menunjukkan bahwa tidak ada petani subak yang skor teknologinya rendah.

\section{Petani Non subak}

Petani non subak dengan jumlah responden sebanyak 69 responden, dimana sebanyak 39 orang petani responden memiliki skor input teknologi yang tinggi dan memperoleh nilai efisiensi lebih besar dari nilai efisiensi ratarata petani non subak yang hanya sebesar 2,22. Artinya, terdapat 39 orang responden yang nilai efisiensinya lebih besar dari 2,22. Namun demikian, terdapat 28 petani responden yang memiliki skor input teknologinya tinggi tetapi memperoleh nilai efisiensi dibawah rata-rata, atau dengan kata lain, nilai efisiensinya lebih rendah dari 2,22. Selain itu, terdapat 2 petani yang skor teknologinya rendah memperoleh nilai efisiensi rendah.

Secara keseluruhan, berdasarkan tabel 2 dapat diartikan bahwa tidak ada variasi hubungan atau keterkaitan yang terpola antara teknologi sosiokultural dengan efisiensi yang diperoleh baik oleh petani subak maupun non subak karena penerapan teknologinya tinggi sehingga rata-rata nilai efisiensinya menjadi tinggi yang ditunjukan dengan nilai $\mathrm{R} / \mathrm{C}$ rata-rata diatas 2 . Penerapan sosiokultural yang baik dapat memperoleh produksi dan efisiensi yang lebih tinggi. Kenyataan ini menunjukan dan menjelaskan terdapat keterkaitan yang linear antara sosiokultural dengan efisiensi usahatani, dimana dari data tabel silang pada tabel 2 dan lampiran $10-11$ diketahui bahwa rata-rata nilai sosiokultural dan efisiensi petani subak lingga merta lebih besar dibandingkan petani non-subak. Hal ini juga dapat diartikan bahwa ada kecenderungan jika skor sosiokultural tinggi maka nilai efisiensi usahatani juga tinggi.

Penerapan teknologi atau adopsi teknologi pada sistem usahatani padi sawah, termasuk pada kelompok subak adalah penggunaan bibit ungul sesuai rekomendasi, penggunaan mesin bajak untuk pengolahan lahan, penggunaan pola tanam tabela, dan penggunaan teknologi mesin pada saat pemanenan pad sawah, seperti mesin combine. Penggunaan teknologi-teknologi tersebut telah memberikan dampak yang signifikan terhadap peningkatan efisiensi biaya produksi dalam usahatani padi sawah, baik petani yang menerapkan sistem subak maupun petani non subak.

\section{Simpulan}

Rata-rata pendapatan petani subak lebih tinggi dibandingkan petani non subak. Ditinjau dari tingkat efisiensi, usahatani padi sawah sistem subak lebih efisien dibandingkan sistem non subak yang diukur dengan menggunakan nilai $\mathrm{R} / \mathrm{C}$ ratio. Anaisis tabel silang dan nilai $\mathrm{R} / \mathrm{C}$ Ratio masing-masing responden diketahui rata-rata nilai skor teknologi dan efisiensi petani subak lebih tinggi dari pada rata-rata nilai skor teknologi dan efisiensi yang diperoleh petani non subak. Dengan kata lain, petani dengan penerapan sosiokultural yang lebih baik dapat memperoleh produksi dan efisiensi yang tinggi. Kenyataan in menunjukan dan menjelaskan ada kecenderungan jika skor sosiokultural tinggi maka nilai efisiensi usahatani juga tinggi. Akan tetapi tidak ditemukan adanya variasi hubungan atau keterkaitan yang terpola antar nilai $\mathrm{R} / \mathrm{C}$ baik pada petani subak maupun non subak karena penerapan teknologinya tinggi sehingga nilai efisiensinya tinggi.

\section{Pustaka}

AAK, 2006. Budidaya Tanaman Padi. Penerbit. Aksi Agraris Kanisius, Yogyakarta.

Aryawan P.S, Windia W, Wijayanti P.U., 2013. Peranan Subak Dalam Aktivitas Pertanian Padi Sawah (Kasus Di Subak Dalem, Kecamatan Kerambitan, Kabupaten Tabanan). E-Jurnal Agribisnis dan Agrowisata ISSN:2301-6523 Vol. 2, No. 1, Januari 2013.

BPS, 2015. Kabupaten Kolaka Dalam Angka. Kantor Pusat Statistik Kabupaten Kolaka, Sulawesi Tenggara.

Pitana, I Gde. 1993. Performance Indikators : A Case of a Newly Developed FMIS in Bali, Indonesia. In Shaul Manor and Jorge Chambouleyron (Eds), Performance Measurement in Farmer-Managed Irrigation Systems. Proceedings of an International Workshop of the Farmer-Managed Irrigation Systems Network, held at Mendoza, Argentina from 12 to 15 November 1991. Colombo : International Irrigation Management Institute (IIMI).

Prabandari, dkk, (2013). Analisis Faktor-Faktor Yang Mempengaruh Produksi Padi Sawah Pada Daerah Tengah dan Hilir Aliran Sungai Ayung (Studi Kasus Subak Mambal, Kabupaten Badung dan Subak Pagutan, Kota Denpasar). E-Jurnal Agribisnis dan Agrowisata ISSN: 2301-6523 Vol. 2, No. 3, Juli 2013.

Soekartawi, 1995, Analisis Usaha Tani, Universitas Indonesia-Press, Jakarta.

Subak Lingga Merta Desa Peoho Kecamatan Watubangga Kabupaten Kolaka Provinsi Sulawesi Tenggara, 2015. Awig-Awig

Sutawan, N 2008. Organisasi Dan Manajemen Subak Di Bali. Denpasar. Pustaka Bali Post.

2003. Kearifan Lokal Dalam Pengelolaan Sumberdaya Air dan Upaya- Upaya pemberdayaan Subak Di Bali. Dalam Prosiding Seminar : Menggagas Pengelolaan Sumberdaya Air Berkelanjutan. Jakarta Food and Agriculture Organization of the United Nation (FAO UN)Kementerian Negara Perencanaan Pembangunan Nasional/Badan Perencanaan Pembangunan Nasional (BAPPENAS).

Windia, Wayan. 2002. Transformasi Sistem Irigasi Subak yang Berlandaskan Konsep Tri Hita Karana. Disertasi (tidak dipublikasikan). Yogyakarta Universitas Gadjah Mada. 